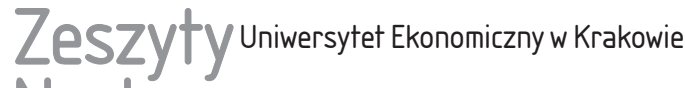 Naukowe
}

\section{Porównanie kondycji rynku mieszkaniowego największych polskich miast w różnych fazach cyklu koniunkturalnego}

\section{Streszczenie}

Celem artykułu jest porównanie rynków mieszkaniowych 17 największych miast w Polsce ze względu na ich zróżnicowanie w czasie. Badany poziom zróżnicowania uwzględnienia analizę odległości od punktu odniesienia, za który przyjęto rynek warszawski. Takie podejście pozwala na ocenę zmniejszania się lub zwiększania dystansu dzielącego największe miasta od stolicy, a unormowanie odległości na analizę zjawiska w czasie. W badaniu wyznaczono odległości między województwami (obiektami). Wykorzystano odległość Canberra, ponieważ uwzględnia poziom zmiennych opisujących obiekty oraz liniowe modele trendu. Wyznaczono również dynamiczne mierniki rozwoju dla miast z zastosowaniem metody TOPSIS.

Badania przeprowadzono w latach 2006-2015, analizując ceny mieszkań na rynku pierwotnym i wtórnym z uwzględnieniem form budownictwa. Przyjęty okres pozwala na analizę zjawiska w różnych fazach cyklu koniunkturalnego. Uzyskane wyniki powinny być istotną wskazówką dla kształtujących politykę mieszkaniową państwa, zwłaszcza jeśli chodzi o miasta znacznie różniące się od Warszawy, takie jak Bydgoszcz, Łódź, Katowice czy Opole.

Iwona Foryś, Uniwersytet Szczeciński, Wydział Nauk Ekonomicznych i Zarządzania, Instytut Ekonometrii i Statystyki, ul. Mickiewicza 64, 71-101 Szczecin, e-mail: iwona.forys@usz.edu.pl

Barbara Batóg, Uniwersytet Szczeciński, Wydział Nauk Ekonomicznych i Zarządzania, Instytut Ekonometrii i Statystyki, ul. Mickiewicza 64, 71-101 Szczecin, e-mail: barbara.batog@usz.edu.pl 
Słowa kluczowe: rynek nieruchomości mieszkaniowych, cykl koniunkturalny, porównania regionalne, odległość Canberra.

Klasyfikacja JEL: R31, C38.

\section{Wprowadzenie}

Rynek nieruchomości jest rynkiem lokalnym, co oznacza, że czynniki wpływające na ten rynek mają również charakter lokalny. Z punktu widzenia inwestorów lub analityków porównujących różne rynki ważne jest jednak tempo rozwoju poszczególnych rynków rodzajowych, zwłaszcza w odniesieniu do tych najlepiej się rozwijających [Foryś 2010]. Punktem odniesienia w Polsce może być aglomeracja warszawska, przede wszystkim ze względu na charakter miasta - stolicy kraju. Takie rynki stanowią swoisty barometr, dzięki któremu można wyznaczać tendencję w przyszłych okresach [Batóg i Foryś 2013]. Są również punktem odniesienia do porównań ze stolicami innych państw [Suarez 2009].

Celem artykułu jest porównanie rynków mieszkaniowych 17 największych miast w Polsce ze względu na ich zróżnicowanie w czasie. Badanie przeprowadzono w latach 2006-2015, analizując ceny mieszkań na rynku pierwotnym i wtórnym. Przyjęty okres pozwala na analizę zjawiska w różnych fazach cyklu koniunkturalnego: hossy w latach 2006-2008, bessy w latach 2009-2012 i wychodzenia z najgłębszego kryzysu w kolejnych latach. Na rynku mieszkaniowym ważne są też przyszłe efekty budownictwa mieszkaniowego, które można opisać za pomocą liczby mieszkań, na których budowę wydano pozwolenia, liczby mieszkań, których budowę rozpoczęto, oraz liczby mieszkań oddanych do użytkowania [Foryś 2013]. Dodatkowo przeprowadzono analizę rynków lokalnych ze względu na formę budownictwa: budownictwo indywidualne, spółdzielcze, na wynajem i sprzedaż, komunalne oraz społeczne czynszowe ${ }^{1}$.

Poziom zróżnicowania badano z uwzględnieniem analizy odległości od punktu odniesienia, za który przyjęto rynek warszawski. Takie podejście pozwoliło na ocenę zmniejszania się lub zwiększania dystansu dzielącego największe miasta od stolicy, a unormowanie odległości pozwoliło na analizę zjawiska w czasie. Uzyskane wyniki powinny być istotną wskazówką w kształtowaniu polityki mieszkaniowej państwa, zwłaszcza w procesie wspierania rozwoju obszarów o największej dysproporcji w stosunku do stolicy.

${ }^{1}$ Porównanie lokalnych rynków nieruchomości dla województw można znaleźć w pracy Ł. Macha [2014]. 


\section{Metoda badawcza}

W badaniach w pierwszej kolejności wyznaczono odległości między badanymi obiektami. Wykorzystano odległość Canberra (wzór (1)), ponieważ uwzględnia poziom zmiennych opisujących obiekty [Gordon 1999, Gatnar i Walesiak 2004, Młodak 2006].

gdzie:

$$
s_{i j}=\sum_{l=1}^{k} \frac{\left|x_{i l}-x_{j l}\right|}{x_{i l}+x_{j l}},
$$

$s_{i j}$ - odległość Canberra między obiektem $i$ a obiektem $j$,

$i, j=1,2, \ldots, n$,

$n$ - liczba obiektów,

$x_{i l}$ - wartość $l$-tej zmiennej dla obiektu $i$,

$x_{j l}$ - wartość $l$-tej zmiennej dla obiektu $j$,

$k$ - liczba zmiennych.

Odległość Canberra przyjmuje wartości z przedziału $\langle 0, \mathrm{k}\rangle$, dlatego wykorzystano względną odległość Canberra (wzór (2)), która przyjmuje wartości z przedziału $\langle 0,1\rangle$.

$$
s_{i j}=\frac{1}{k} \sum_{l=1}^{k} \frac{\left|x_{i l}-x_{j l}\right|}{x_{i l}+x_{j l}} .
$$

Im względna odległości Canberra jest bliżej 0, tym bardziej podobne są badane obiekty, a im bliżej 1, tym obiekty są mniej podobne ${ }^{2}$.

W dalszej kolejności wykorzystano liniowe modele trendu. Estymacja i weryfikacja modeli ekonometrycznych jest opisana w wielu opracowaniach (np. [Pawłowski 1978, Johnston 1991]).

W ostatniej kolejności wyznaczono mierniki rozwoju dla miast z zastosowaniem metody TOPSIS (technique for order preference by similarity to ideal solution) [Hwang i Yoon 1981]. Normalizacji zmiennych dokonano za pomocą unitaryzacji zerowanej [Kukuła 2000]. Wykorzystano dynamiczną wersję miernika rozwoju, czyli wzorzec i antywzorzec został wyznaczony na podstawie wszystkich lat. W metodzie TOPSIS wartości miernika rozwoju są wyznaczane według wzoru (3).

$$
q_{i}=\frac{d_{i, 0}}{d_{i, 0}+d_{i, 1}},
$$

gdzie:

$q_{i}$ - wartość miernika rozwoju dla obiektu $i$,

${ }^{2}$ Odległość Canberra została wykorzystana do badania podobieństwa przez I. Foryś i B. Batóg [2016]. 
$d_{i, 0}$ - odległość euklidesowa między obiektem $i$ a antywzorcem,

$d_{i, 1}$ - odległość euklidesowa między obiektem $i$ a wzorcem ${ }^{3}$.

Miernik rozwoju przyjmuje wartości z przedziału $\langle 0,1\rangle$. Im jego wartość jest bliższa 1, tym wyżej dany obiekt znajduje się w rankingu.

\section{Dane wykorzystane w badaniach}

Analizę dysproporcji rynków mieszkaniowych w 17 największych polskich miastach przeprowadzono, wykorzystując średnie kwartalne ceny ofertowe i transakcyjne mieszkań na rynku pierwotnym i wtórnym publikowane przez NBP, począwszy od trzeciego kwartału 2007 r. Wykorzystano również informacje z zasobu statystki publicznej dotyczące efektów budownictwa mieszkaniowego na każdym etapie realizacji projektu, tzn. uzyskania pozwolenia na budowę, rozpoczęcia inwestycji oraz oddania do użytkowania. Z Banku Danych Lokalnych GUS pozyskano dane kwartalne za lata 2006-2016 dotyczące:

- liczby mieszkań oddanych do użytkowania według poszczególnych form budownictwa,

- liczby mieszkań, na których budowę wydano pozwolenia,

- liczby mieszkań, których budowę rozpoczęto.

W celu zachowania porównywalności danych wielkości te przeliczono na 1000 mieszkańców. W rezultacie dla wybranych miast analizowano następujące zmienne:

- jednostkowe ceny ofertowe mieszkań na rynku pierwotnym $\left(\mathrm{z} \nmid / \mathrm{m}^{2}\right)$,

- jednostkowe ceny ofertowe mieszkań na rynku wtórnym $\left(\mathrm{z} t / \mathrm{m}^{2}\right)$,

- jednostkowe ceny transakcyjne mieszkań na rynku wtórnym $\left(\mathrm{z} / \mathrm{m}^{2}\right)$,

- liczbę mieszkań oddanych do użytkowania na 1000 mieszkańców według poszczególnych form budownictwa,

- liczbę mieszkań na 1000 mieszkańców, na których budowę wydano pozwolenia,

- liczbę mieszkań na 1000 mieszkańców, których budowę rozpoczęto.

Dla badanych zmiennych analizowano dynamikę oraz odległości od wzorca, wykorzystując w tym celu wyznaczone miary odległości Canberra oraz wartości miernika rozwoju wyznaczone za pomocą metody TOPSIS.

${ }^{3} \mathrm{~W}$ przypadku zastosowania unitaryzacji zerowanej antywzorzec to wektor składający się z samych zer, a wzorzec - wektor składający się z samych jedynek. 


\section{Ceny mieszkań na rynku pierwotnym i rynku wtórnym}

Ceny mieszkań są wypadkową sytuacji na danym rynku, przy czym ich zróżnicowanie na rynku pierwotnym (ceny mieszkań nowo wybudowanych) oraz wtórnym (sprzedaż powtórna zasobu istniejących mieszkań) wzajemnie się uzupełniają [Boelhouwer i Vries 2005]. Wskazują na reakcję deweloperów na zmiany rynkowe, odzwierciedlając jednocześnie ich przyszłe oczekiwania co do kierunku zmian [Bahadir i Mykhaylova 2014]. Wraz z nowymi inwestycjami zmienia się sytuacja na rynku wtórnym [Foryś 2011]. Sprzedający mieszkania odnoszą swoje ceny ofertowe do ofert deweloperów na rynku pierwotnym, podobnie jak deweloperzy korygują swoje oferty, uwzględniając zawarte umowy na rynku wtórnym [Gibler i Zahirovich-Herbert 2014].

Analizę cen mieszkań w ostatniej dekadzie determinuje ogólnoświatowy kryzys gospodarczy końca 2008 r., skutkujący spadkiem cen nieruchomości. W Polsce na rynku pierwotnym ceny mieszkań ustabilizowały się już w 2009 r. (rys. 1).

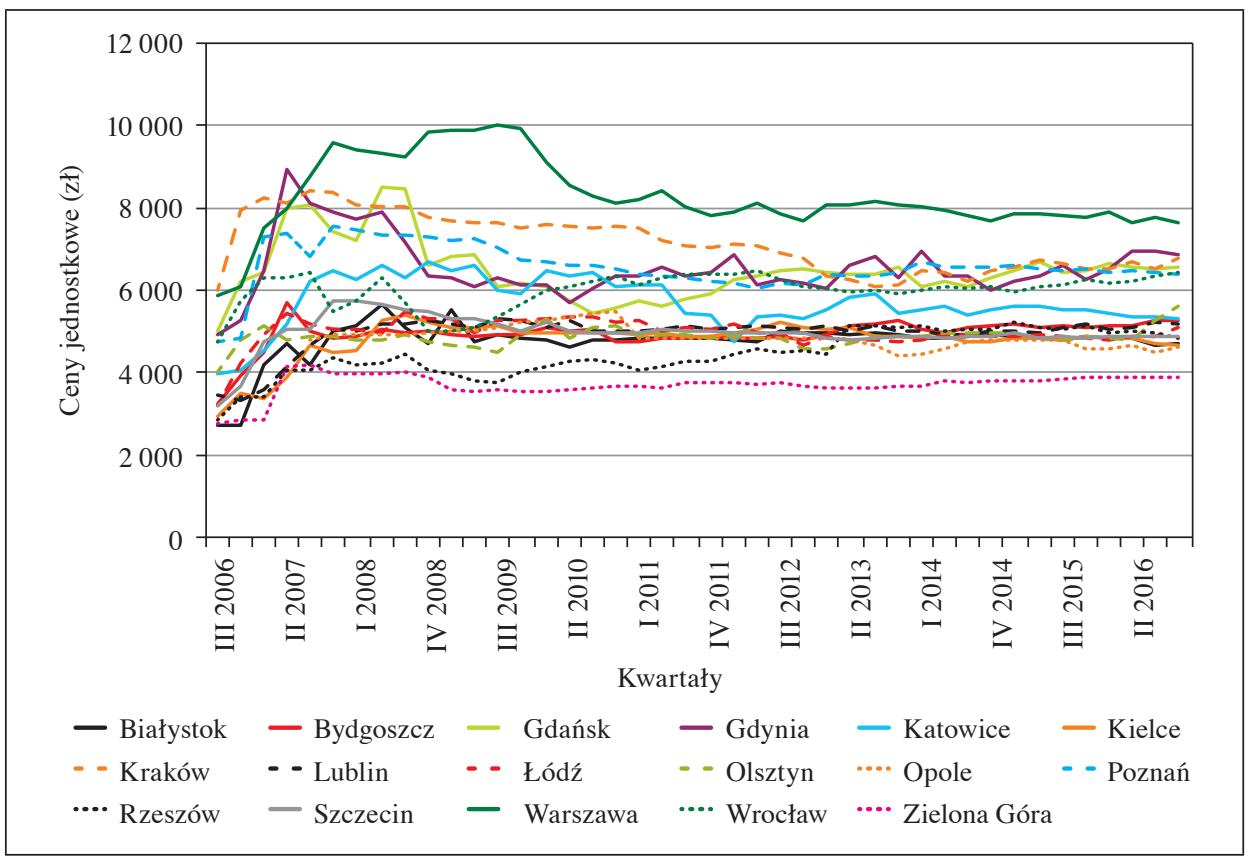

Rys. 1. Ceny jednostkowe na rynku pierwotnym w latach 2006-2016

Źródło: opracowanie własne na podstawie danych NBP pochodzących z Bazy cen nieruchomości mieszkaniowych BaRN (https://www.nbp.pl/publikacje/rynek_nieruchomosci/ceny_mieszkan.xls, data dostępu: 20.04.2017). 
Tendencja wzrostowa w latach 2006-2008 została zahamowana w trzecim kwartale 2008 r. i po gwałtownym spadku notowanym do połowy 2009 r. w większości miast pozostaje na podobnym poziomie do końca 2016 r. Ceny mieszkań w Warszawie w badanym okresie odbiegają znacznie od cen w innych miastach (nawet o 2 tys. zł $/ \mathrm{m}^{2} \mathrm{w}$ stosunku do górnej granicy cen w innych miastach). Rynek warszawski odbiega również od ogólnej tendencji, gdyż ceny osiągnięte w $2008 \mathrm{r}$. utrzymały się do końca 2009 r., a gwałtowny spadek cen na rynku pierwotnym miał miejsce dopiero w 2010 r. Najniższe ceny na rynku pierwotnym w całym badanym okresie występowały w Zielonej Górze. W ostatnich czterech latach ceny na rynkach pierwotnych badanych miast ustabilizowały się na dwóch poziomach: 5 tys. $\mathrm{z} / \mathrm{m}^{2}$ oraz 6,5 tys. $\mathrm{z} / \mathrm{m}^{2}$, z wyjątkiem Warszawy, gdzie ceny oscylowały wokół 8 tys. zł $/ \mathrm{m}^{2}$.

Na rys. 2 przedstawiono różnice między jednostkowymi cenami ofertowymi a cenami transakcyjnymi na rynku wtórnym. Ceny ofertowe rynek koryguje, obniżając je w zależności od fazy cyklu koniunkturalnego oraz efektywności informacyjnej danego rynku. Na rynku wtórnym zachowania kupujących są podobne, jeśli chodzi o tendencje, do rynku pierwotnego, ale ceny są zdecydowanie niższe. Ceny ofertowe naśladują rynek pierwotny, jednostkowe ceny transakcyjne (rys. 2) są jednak przeciętnie o 1000 zł niższe.

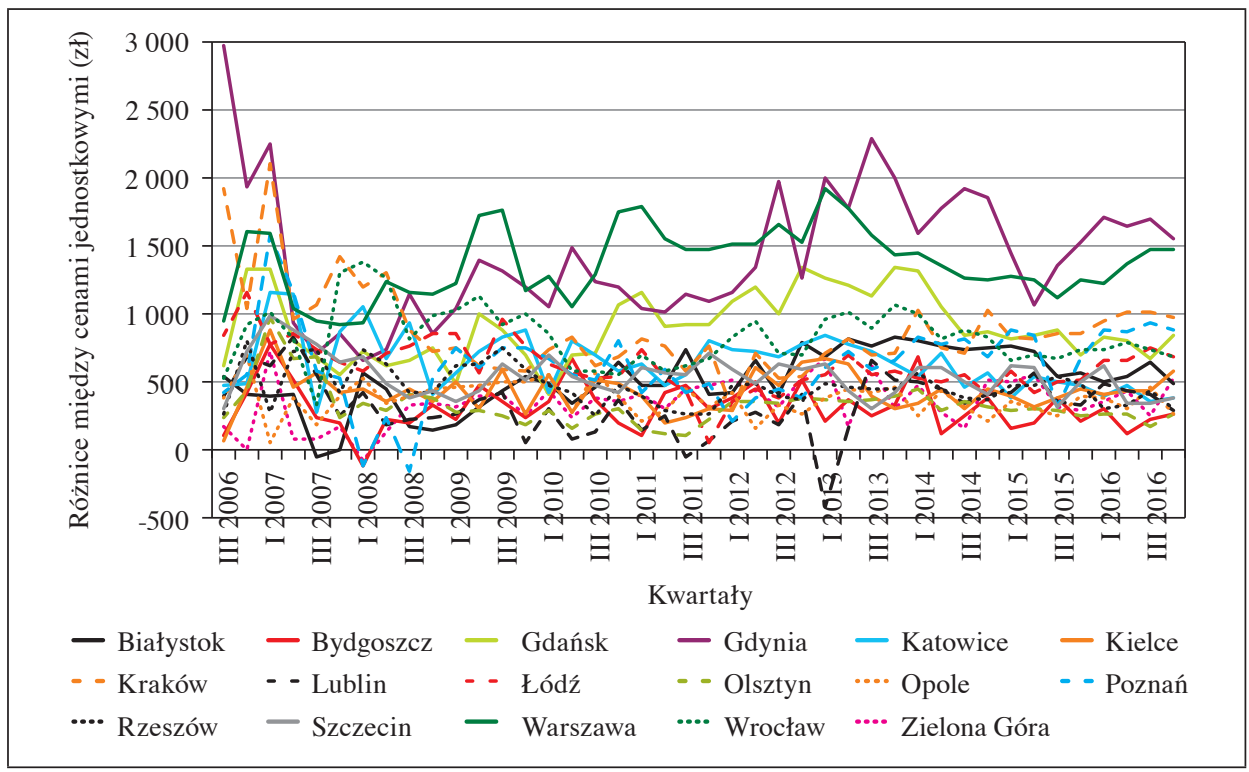

Rys. 2. Różnice między jednostkowymi cenami ofertowymi a cenami transakcyjnymi na rynku wtórnym w latach 2006-2016

Źródło: jak do rys. 1. 
W tym przypadku również zdecydowanie wyróżnia się rynek warszawski. Rynek wtórny zdecydowanie szybciej odebrał negatywne sygnały z otoczenia i spadki cen miały już miejsce od początku 2008 r., natomiast stabilizację cen odnotowywano od 2010 r. Najniższe ceny występowały w ostatnich sześciu latach w Zielonej Górze (poziom 3,5 tys. zł $/ \mathrm{m}^{2}$ cen ofertowych oraz 3 tys. zł $/ \mathrm{m}^{2}$ cen transakcyjnych).

\section{Badanie dysproporcji na rynku mieszkaniowym z wykorzystaniem rynku warszawskiego jako punktu odniesienia}

Potwierdzeniem zauważanych dysproporcji rynku warszawskiego są uzyskane wartości odległości Canberra (rys. 3) unormowanej na przedział $\langle 0,1\rangle$ obliczonej dla cen jednostkowych jako zmiennych składowych (jednostkowe ceny ofertowe mieszkań na rynku pierwotnym, zł/ $\mathrm{m}^{2}$; jednostkowe ceny ofertowe mieszkań na rynku wtórnym, zł/ $\mathrm{m}^{2}$; jednostkowe ceny transakcyjne mieszkań na rynku wtórnym, zł $/ \mathrm{m}^{2}$ ). Odległość ta została zastosowana w analizach ze względu na formułę uwzględniającą poziom zmiennych składowych.

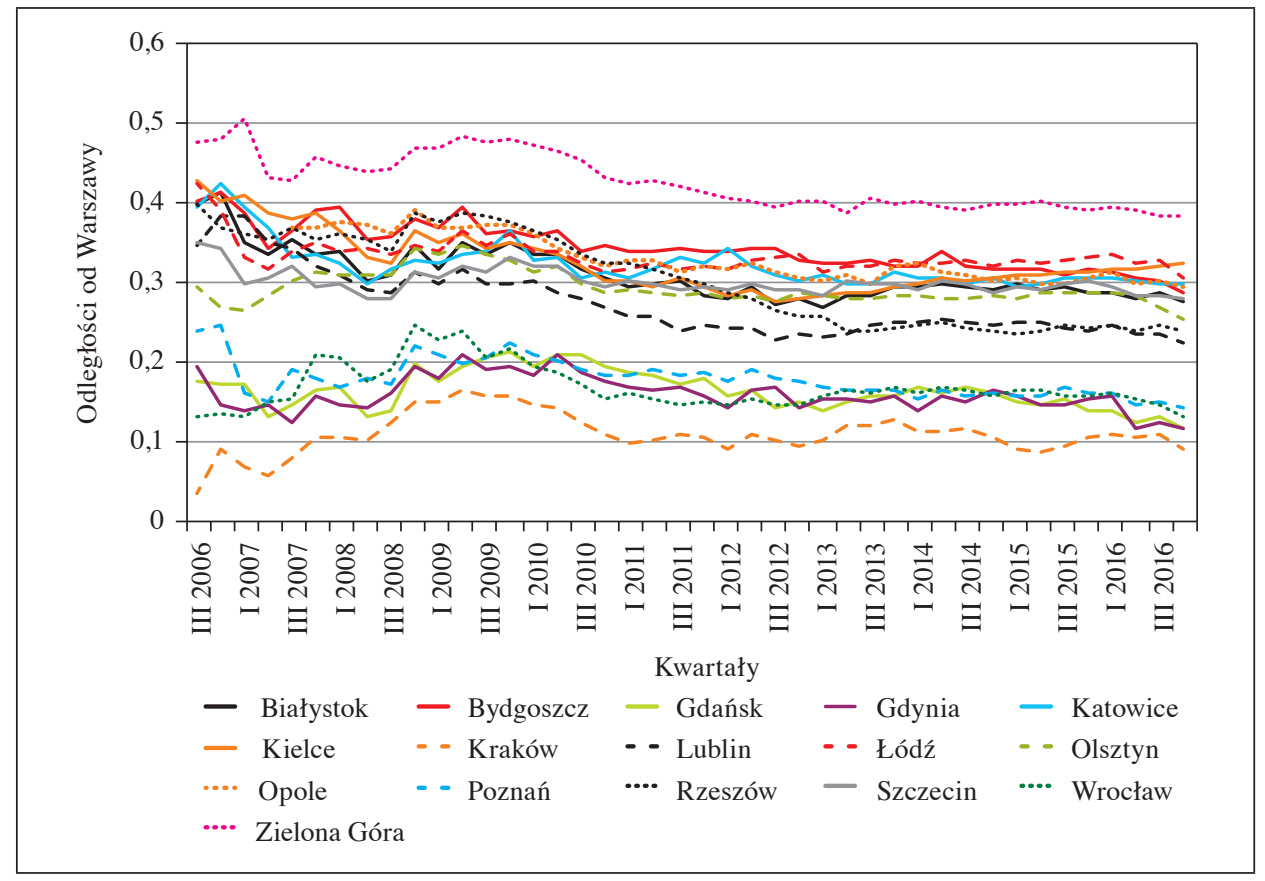

Rys. 3. Odległość Canberra badanych miast od Warszawy obliczone na podstawie trzech cen jednostkowych w latach 2006-2016

Źródło: obliczenia własne. 
Najwyższe wartości uzyskano dla Zielonej Góry, najniższe dla Krakowa. Z wyjątkiem Krakowa w latach 2006-2008 oraz Rzeszowa trend wartości miary odległości Canberra dla cen jednostkowych ma podobny przebieg we wszystkich miastach. W latach 2012-2016 uzyskane wartości miary mieszczą się w przedziale $0,10-0,40$, wskazując tym samym na niski poziom podobieństwa do rynku warszawskiego.

Tabela 1. Wyniki oszacowania parametrów trendów liniowych dla odległości Canberra między Warszawą a pozostałymi miastami dla cen jednostkowych $\left(\mathrm{z} ł / \mathrm{m}^{2}\right)$

\begin{tabular}{|l|c|c|c|c|}
\hline \multicolumn{1}{|c|}{ Miasto } & Okres & $\begin{array}{c}\text { Ocena para- } \\
\text { metru trendu } \\
\text { liniowego }\end{array}$ & Statystyka $t$ & $p$ \\
\hline Białystok & I kw. 2014 - IV kw. 2016 & $-0,0015$ & $-4,581$ & 0,001 \\
\hline Bydgoszcz & III kw. 2006 - IV kw. 2016 & $-0,0022$ & $-13,873$ & 0,000 \\
\hline Gdańsk & II kw. 2014 - IV kw. 2016 & $-0,0050$ & $-9,064$ & 0,000 \\
\hline Gdynia & IV kw. 2012 - II kw. 2016 & trend stały, spadek w III i IV kw. 2016 \\
\hline Katowice & III kw. 2012- IV kw. 2016 & \multicolumn{3}{|c|}{ trend stały } \\
\hline Kielce & III kw. 2012 - IV kw. 2016 & 0,0027 & 18,374 & 0,000 \\
\hline Kraków & III kw. 2006 - IV kw. 2016 & \multicolumn{3}{|c|}{ brak prawidłowości } \\
\hline Lublin & III kw. 2006 - IV kw. 2016 & $-0,0030$ & $-10,994$ & 0,000 \\
\hline Łódź & I kw. 2010 - III kw. 2016 & trend stały, spadek w IV kw. 2016 \\
\hline Olsztyn & II kw. 2011 - II kw. 2016 & trend stały, spadek w III i IV kw. 2016 \\
\hline Opole & III kw. 2006 - IV kw. 2016 & $-0,0023$ & $-12,026$ & 0,000 \\
\hline Poznań & I kw. 2010 - IV kw. 2016 & $-0,0019$ & $-12,411$ & 0,000 \\
\hline Rzeszów & III kw. 2006 - IV kw. 2016 & $-0,0043$ & $-15,501$ & 0,000 \\
\hline Szczecin & III kw. 2010 - II kw. 2016 & trend stały, spadek w III i IV kw. 2016 \\
\hline Wrocław & I kw. 2013 - II kw. 2016 & trend stały, spadek w III i IV kw. 2016 \\
\hline Zielona Góra & III kw. 2006 - IV kw. 2016 & $-0,0024$ & $-10,207$ & 0,000 \\
\hline
\end{tabular}

Źródło: obliczenia własne.

Podsumowaniem analizy cen mieszkań w badanych latach w stosunku do rynku warszawskiego może być oszacowanie parametrów funkcji trendu liniowego, który wskazuje tendencję odległości poszczególnych rynków w stosunku do rynku referencyjnego. W tabeli 1 zaprezentowano wyniki dla okresów (kwartałów), w których zauważono stałą tendencję miary odległości Canberra (cały badany okres lub jego część). Jeśli tendencja jest stała, wówczas odległość od Warszawy nie zmienia się, gdy mają współczynnik kierunkowy ujemny, wówczas odległość od Warszawy zmniejsza się, w przeciwnym wypadku zwiększa się. W przypadku rynku krakowskiego nie ma stałej tendencji - w krótkich okresach 
odległość od Warszawy raz rośnie, raz maleje. W większości miast parametr ma znak ujemny, co świadczy o zmniejszaniu się odległości od Warszawy. Wyjątkiem są Kielce, dla których oszacowany współczynnik kierunkowy jest dodatni, więc odległość od Warszawy wzrasta.

W następnej kolejności wyznaczono odległości Canberra między Warszawą a pozostałymi badanymi miastami, wykorzystując jako zmienne składowe cztery wskaźniki mieszkań oddanych do użytkowania na 1000 mieszkańców według formy budownictwa - spółdzielcze, komunalne, przeznaczone na sprzedaż lub wynajem oraz indywidualne (rys. 4). Największe podobieństwo do rynku warszawskiego w latach 2006-2010 ze względu na wymienione wskaźniki wykazuje Zielona Góra, natomiast w latach 2012-2015 Opole. Najniższą wartość odległości od Warszawy można zauważyć na najbardziej aktywnych rynkach Wrocławia i Gdańska. Największe wahania miary można zauważyć w przypadku Kielc.

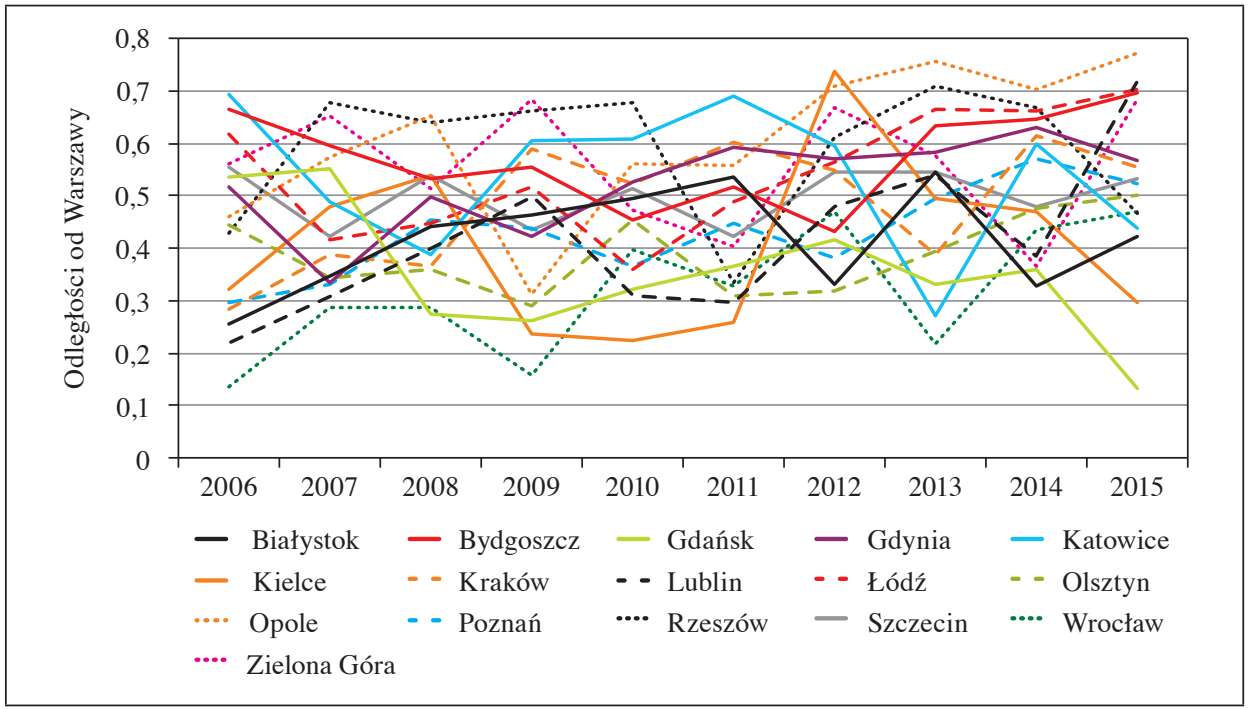

Rys. 4. Odległość Canberra badanych miast od Warszawy dla liczby mieszkań przypadających na 1000 mieszkańców według form budownictwa w latach 2006-2015 Źródło: obliczenia własne.

Przyjmując jako zmienną liczbę mieszkań oddanych do użytkowania według poszczególnych form budownictwa, ale nie odnosząc tej wielkości do liczby mieszkańców (rys. 5), najmniejszą odległość od rynku warszawskiego można zauważyć dla Wrocławia i Krakowa, gdzie dominuje budownictwo wielorodzinne, natomiast największe wartości miary odległości Canberra - dla Opola, Zielonej Góry i Katowic, w których dominuje budownictwo indywidualne. 
Jeśli chodzi o przyszłe efekty budownictwa mieszkaniowego, miarą wskazującą na optymizm inwestorów jest liczba wydanych pozwoleń na budowę mieszkań. Omawiany wskaźnik w przeliczeniu na 1000 mieszkańców pozwala porównać aktywność lokalnych rynków w analizowanych miastach. W większości miast nastąpił regres w 2009 r. będący efektem rozpoczynającego się kryzysu gospodarczego. Nie wszystkie rynki zareagowały jednak w tym samym czasie, niektóre z rocznym opóźnieniem (np. Warszawa, Gdynia, Gdańsk, Poznań czy Zielona Góra). W miastach, takich jak Opole, Katowice, Szczecin czy Kraków, po regresie w 2009 r., w kolejnym roku odnotowano zwiększenie aktywności inwestorów wyrażające się zmianą tendencji w liczbie uzyskanych pozwoleń na budowę nowych mieszkań.

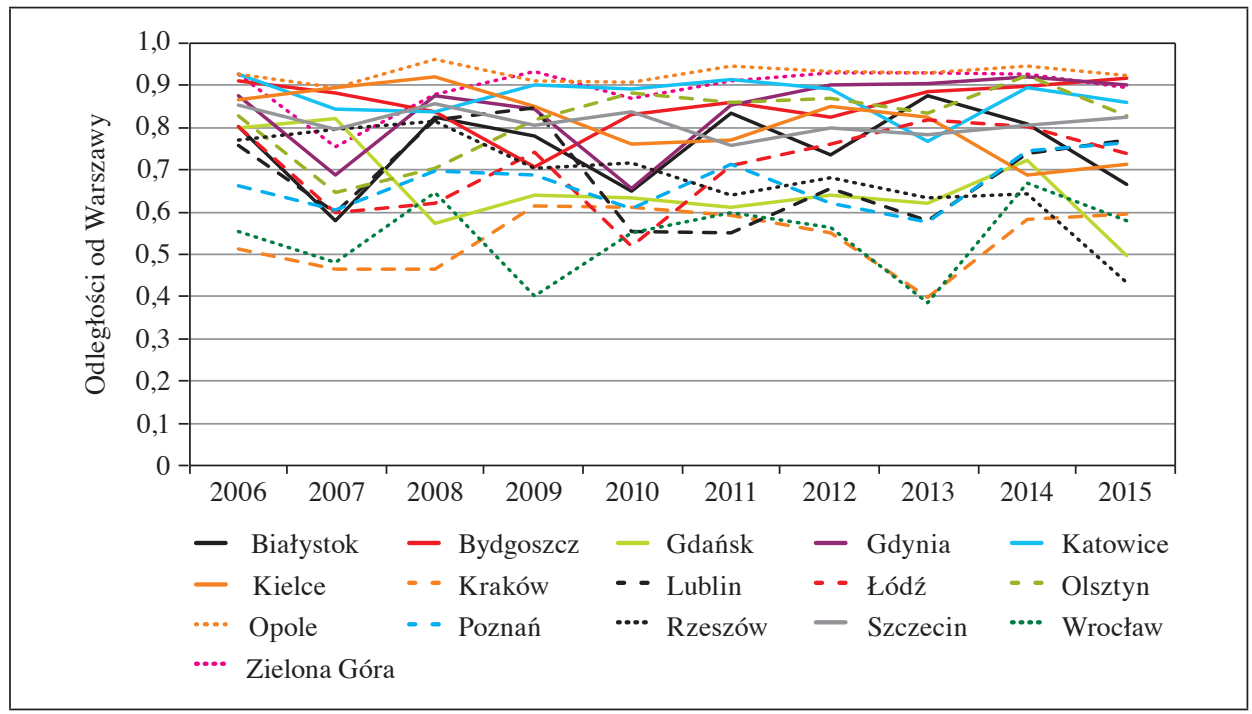

Rys. 5. Odległość Canberra badanych miast od Warszawy dla liczby mieszkań według form budownictwa w latach 2006-2015

Źródło: obliczenia własne.

Kolejny spadek wskaźnika widoczny jest w większości miast w 2013 r. Od 2014 r. widoczna jest zaś tendencja wzrostowa wskaźnika we wszystkich analizowanych miastach. W całym analizowanym okresie najwyższe wartości wskaźnika, sięgające 16-18 pozwoleń na 1000 mieszkańców, odnotowano w Krakowie, Warszawie, Wrocławiu i Gdańsku. Są to zdecydowanie najważniejsze rynki nowych inwestycji mieszkaniowych w Polsce. Najniższe wartości wskaźnika wystąpiły w przypadku Olsztyna i Opola. Różnica między wskaź- 
nikami dla poszczególnych miast jest nawet dziewięciokrotna. Najwięcej miast odnotowało wskaźnik w przedziale $2-8$ pozwoleń przypadających na 1000 mieszkańców.

Uzyskanie pozwolenia na budowę mieszkań nie jest jednoznaczne z rozpoczęciem inwestycji. Załamanie rynku jest częstą przyczyną odłożenia decyzji o budowie, zazwyczaj do trzech lat (wynika to z ważności pozwolenia na budowę). Wskaźnik mieszkań, których budowę rozpoczęto, potwierdza przesunięcie decyzji inwestorów o budowie nawet o dwa lata w stosunku do uzyskanych pozwoleń na budowę w 2008 r. Najbardziej aktywne rynki w całym badanym okresie to Kraków oraz Gdańsk. W latach 2006-2008 oraz 2014-2015 wysoką wartość wskaźnika zanotowano również w Warszawie. Najniższą aktywność w całym badanym okresie można zauważyć w Opolu oraz Łodzi. Różnica między wskaźnikami dla miast jest nawet siedmiokrotna. Najwięcej miast ma wskaźnik z przedziału 2-6 mieszkań, których budowę rozpoczęto, na 1000 mieszkańców.

Ze względu na cykl inwestycyjny liczba mieszkań oddanych do użytkowania w stosunku do liczby mieszkań, których budowę rozpoczęto, wykazuje opóźnienie do dwóch lat. Dlatego pierwsze załamanie rynku, będące efektem kryzysu gospodarczego, jest zauważalne w latach 2009-2010. Wskaźnik ten jest również związany z liczbą rozpoczynanych nowych inwestycji. Większość inwestorów w latach 2009-2012 miała kłopoty ze sprzedażą wybudowanych mieszkań, stąd awersja do rozpoczynania nowych inwestycji. Jeśli chodzi o wartość badanego wskaźnika, w latach 2006-2009 dominują inwestycje w Krakowie i Warszawie, w latach 2010-2013 we Wrocławiu i Gdańsku, natomiast w latach 2014-2016 w Rzeszowie i Wrocławiu. W większości miast w całym badanym okresie wskaźnik mieścił się w przedziale 2-10 mieszkań oddawanych do użytkowania na 1000 mieszkańców.

Analiza miary odległości Canberra (dla zmiennych: liczba mieszkań, na których budowę wydano pozwolenia, liczba mieszkań, których budowę rozpoczęto, oraz liczba mieszkań oddanych do użytkowania) pozwala wskazać miasta znacząco różniące się od pozostałych pod względem aktywności lokalnych rynków. Można wyróżnić miasta „gorsze” od Warszawy, czyli takie, w których wartości wszystkich trzech zmiennych były niższe niż w Warszawie (rys. 6), oraz miasta „lepsze” od Warszawy, czyli takie, w których wartości zmiennych były wyższe niż w Warszawie w większości badanych lat, a zwłaszcza w ostatnich trzech latach (rys. 7). Miasta z wyższymi wartościami zmiennych to Gdańsk, Kraków, Rzeszów i Wrocław. Dla tych miast odległość od 2011 r. jest mniejsza niż 0,2.

W następnym etapie wyznaczono wartości miernika rozwoju za pomocą metody TOPSIS. Zmiennymi były liczba mieszkań, na których budowę wydano pozwolenia, liczba mieszkań, których budowę rozpoczęto, oraz liczba mieszkań oddanych do użytkowania (wszystkie w przeliczeniu na 1000 mieszkańców). 
Metodę TOPSIS zastosowano w taki sposób, że wzorzec i antywzorzec zostały wyznaczone dla wszystkich lat łącznie. Z tego względu możliwe jest porównywanie w czasie (rys. 8).

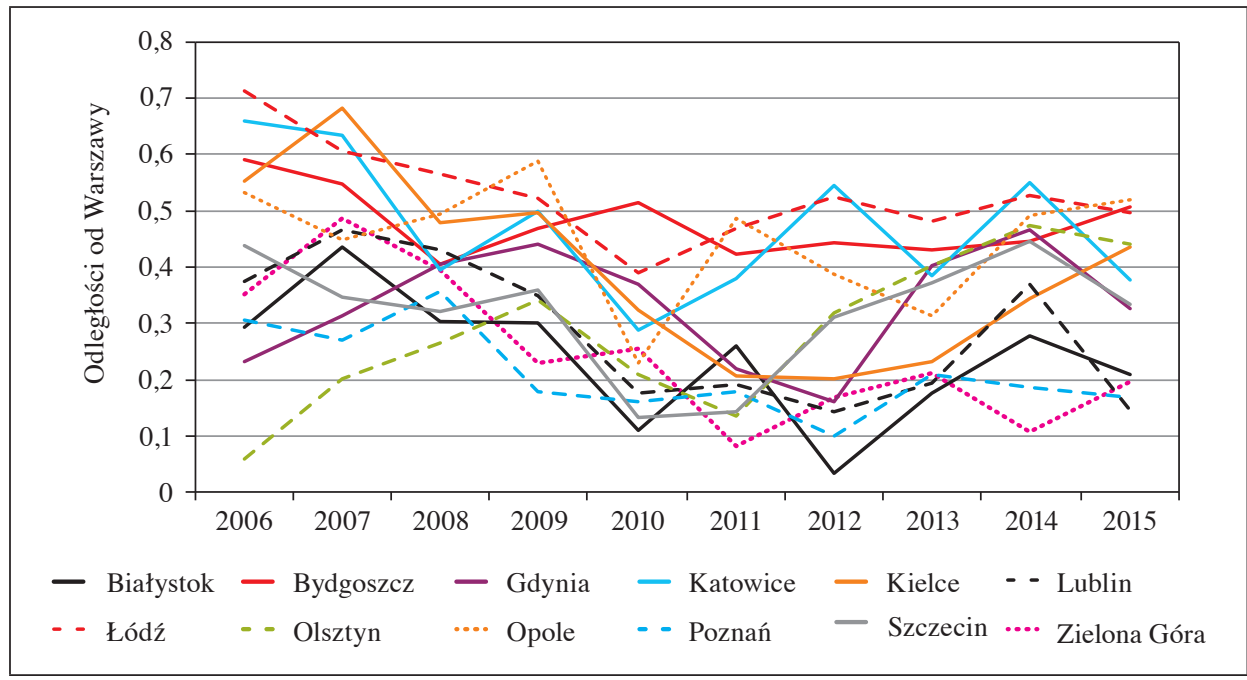

Rys. 6. Odległość Canberra badanych miast od Warszawy w latach 2006-2015 - miasta z niższymi wartościami analizowanych zmiennych

Źródło: obliczenia własne.

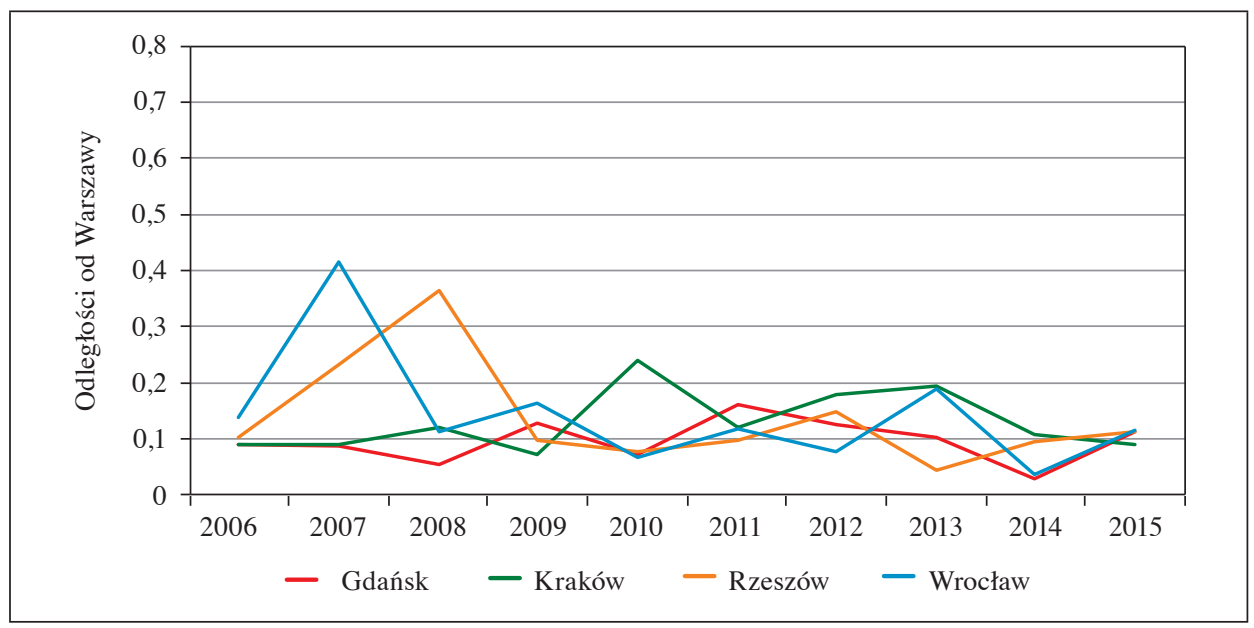

Rys. 7. Odległość badanych miast od Warszawy w latach 2006-2015 - miasta z wyższymi wartościami analizowanych zmiennych

Źródło: obliczenia własne. 


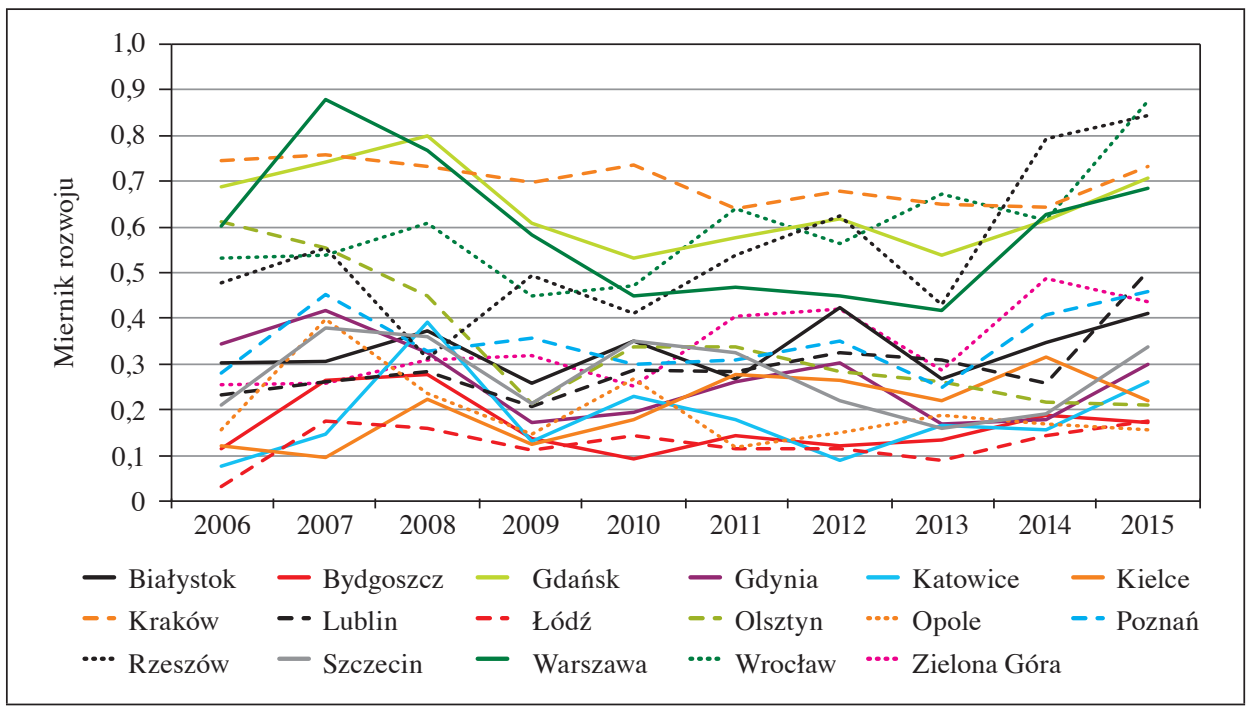

Rys. 8. Wartości miernika rozwoju wyznaczonego metodą TOPSIS w latach 2006-2015 Źródło: obliczenia własne.

Od 2011 r. miernik rozwoju dla Gdańska, Krakowa, Rzeszowa i Wrocławia przyjmuje wartości wyższe niż dla Warszawy. Najniższe wartości miernika rozwoju charakteryzowały Bydgoszcz, Łódź, Katowice i Opole.

Uzyskane wyniki wskazują na duże różnice między poziomem badanych zmiennych w największych miastach a Warszawą i grupą kilku miast „lepszych” od Warszawy. Są to przesłanki zarówno dla decydentów kierujących wsparcie finansowe w ramach programów mieszkaniowych do miast „gorszych” od stolicy, jak również dla inwestorów typujących atrakcyjne rynki, by zaangażować kapitał w nowe projekty mieszkaniowe.

\section{Wnioski}

Cena jest wypadkową popytu i podaży na rynku, dlatego zauważalne tendencje w dynamice i kierunku zmian cen jednostkowych są również barometrem sytuacji na rynku mieszkaniowym. Podobną funkcję pełni wskaźnik aktywności podmiotów na rynku mierzony liczbą transakcji rynkowych. Celem artykułu było porównanie rynków mieszkaniowych 17 największych miast w Polsce w latach 2006-2015.

Uzyskane wyniki potwierdzają zmiany na lokalnych rynkach w badanych miastach po 2008 r. Począwszy od pierwszego kwartału 2009 r., spadają ceny 
jednostkowe mieszkań zarówno na rynku pierwotnym, jak i na rynku wtórnym, spada popyt na mieszkania, co widać w malejącej liczbie zawieranych umów. Na podstawie badanych dysproporcji między największymi miastami w Polsce można zauważyć, że zróżnicowanie wartości badanych zmiennych jest większe w okresie hossy (lata 2006-2008) niż bessy w latach kolejnych, kiedy są one bardziej skupione. Oznacza to, że rynek mieszkaniowy w większości analizowanych miast w czasie hossy znacznie się różni od rynków najlepszych. W okresie dekoniunktury rynki zachowują się podobnie, a analizowane tendencje zmiennych są w większości przypadków zbieżne.

Zaobserwowane prawidłowości dotyczą zarówno zmian na rynku wtórnym w kontekście rynku pierwotnego (nowych efektów budownictwa mieszkaniowego), jak i analiz z uwzględnieniem form budownictwa.

Niezależnie od cyklu koniunkturalnego w skali kraju występują rynki słabsze (gorsze od przyjętego punktu odniesienia) oraz rynki lepsze. Okazało się również, że rynek warszawski nie jest w każdym badanym roku liderem mieszkaniowym w świetle badanych zmiennych, istotnych z punktu widzenia opisu zjawisk na tym rynku. Liderami są również Kraków, Wrocław czy Gdańsk. Uzyskane wyniki mogą być cenną wskazówką służącą do wyboru punktu odniesienia w innych badaniach rynków mieszkaniowych. Stanowią również materiał porównawczy dla decydentów i inwestorów na rynku mieszkaniowym.

\section{Literatura}

Bahadir B., Mykhaylova O. [2014], Housing Market Dynamics with Delays in the Construction Sector, ,Journal of Housing Economics”, vol. 26, https://doi.org/10.1016/ j.jhe.2014.09.005.

Batóg B., Foryś I. [2013], Modele cen nieruchomości mieszkaniowych na rynku lokalnym [w:] Zastosowanie metod ilościowych w modelowaniu i prognozowaniu zjawisk spoteczno-gospodarczych, red. B. Pawełek, Wydawnictwo Uniwersytetu Ekonomicznego w Krakowie, Kraków.

Boelhouwer P., Vries P. [2005], Local House Price Developments and Housing Supply, „Property Management”, vol. 23, nr 2, https://doi.org/10.1108/02637470510589968.

Foryś I. [2010], The Cox Proportional Hazards Model in the Analysis of Property Transactions, „Folia Oeconomica Stetinesia”, vol. 8(16), Wydawnictwo Naukowe Uniwersytetu Szczecińskiego, Szczecin, https://doi.org/10.2478/v10031-009-0017-3.

Foryś I. [2011], Społeczno-gospodarcze determinanty rozwoju rynku mieszkaniowego w Polsce. Ujęcie ilościowe, Rozprawy i Studia, t. 793, Wydawnictwo Uniwersytetu Szczecińskiego, Szczecin.

Foryś I. [2013], Przestrzenne zróżnicowanie dynamiki wybranych wskaźników budownictwa mieszkaniowego w Polsce w latach 2003-2013, Zeszyt Naukowy Uniwersytetu Szczecińskiego, nr 826, Studia i Prace WNEiZ, nr 37, t. 1, red. B. Kryk, Szczecin. 
Foryś I., Batóg B. [2016], Porównanie struktury mieszkań w obrocie w wybranych miastach pótnocno-zachodniej Polski, ,Zeszyty Naukowe Uniwersytetu Ekonomicznego w Krakowie", nr 9(957), https://doi.org./10.15678/ZNUEK.2016.0957.0904.

Gatnar E., Walesiak M. [2004], Metody statystycznej analizy wielowymiarowej w badaniach marketingowych, Wydawnictwo Akademii Ekonomicznej we Wrocławiu, Wrocław.

Gibler K.M., Zahirovich-Herbert V. [2014], The Effect of New Residential Construction on Housing Prices, ,Journal of Housing Economics”, vol. 26, https://doi.org/10.1016/ j.jhe.2014.06.003.

Gordon A.D. [1999], Classification, Chapman and Hall/CRC, USA.

Hwang C.L., Yoon K. [1981], Multiple Attribute Decision Making. Methods and Applications. A State-of-the-Art Survey, Springer-Verlag, Berlin.

Johnston J. [1991], Econometric methods, McGraw-Hill International Editions.

Kukuła K. [2000], Metoda unitaryzacji zerowanej, Wydawnictwo Naukowe PWN, Warszawa.

Mach Ł. [2014], Próba budowy homogenicznych grup województw w obszarze lokalnych rynków nieruchomości mieszkaniowych, ,Metody Ilościowe w Badaniach Ekonomicznych", t. XV/3.

Młodak A. [2006], Analiza taksonomiczna w statystyce regionalnej, Difin, Warszawa.

Pawłowski Z. [1978], Ekonometria, PWE, Warszawa.

Suarez J.L. [2009], European Real Estate Markets, Palgrave Macmillan, New York.

\section{The Distance between the Largest Polish Cities - the Housing Market in Different Phases of the Business Cycle}

The paper compares the housing markets in the 17 biggest cities in Poland according to their diversity in time. The level of diversification is analyzed by examining the distance from the Warsaw housing market, which was the benchmark. This approach enabled an evaluation of the distances between Warsaw, Poland's capital city, and other cities. Standardised measures were applied to evaluate changes in time. In the research, the Canberra distance was applied because it depends on relative differences between the values of the variables analysed. The parameters of the trends of the distances were estimated. Additionally, dynamic development measures were calculated using the TOPSIS method.

The analysis concerns the prices of apartments on the primary and secondary markets in the years 2006-2016. This period includes different phases of business cycle: the boom in 2006-2008, the fall in 2009-2012 and the slow climb out the deep crisis afterwards. Other features of the housing market were also considered. The results obtained may provide clues to how governmental housing policy will shape up in order to support the less developed housing markets in Bydgoszcz, Łódź, Katowice and Opole.

Keywords: housing market, business cycle, regional comparisons, Canberra distance. 